\title{
Influence of Long-Term Fertilization on Phosphorus, Potassium, Magnesium, and Sulfur Content in Soil
}

\author{
Zbigniew Mazur*, Teofil Mazur \\ Chair of Environmental Chemistry, University of Warmia and Mazury in Olsztyn, \\ pl. Łódzki 4, 10-727 Olsztyn, Poland \\ Received: 24 April 2014 \\ Accepted: 3 August 2014
}

\begin{abstract}
The present work discusses the influence of long-term, annually applied fertilization with manure, slurry, and NPK on the accumulation of total and available forms of phosphorus, potassium, and magnesium in soils, as well as total sulfur content. The increase in total phosphorus, potassium, and magnesium content under the influence of fertilization was significant when compared to the control group, and determined as : P-21.8\%, K-36.2\%, Mg-57.4\%, S-28.5\% in lessive soil, and P-24.7\%, K-26.9\%, Mg-54.2\%, and S-34.7\% in brown soil. An increase of available forms in the total content of macronutrients was noted. The percentage increase in relation to the control group, respectively for lessive and brown soils, was as follows: P-2.6\% and $2.4 \%, \mathrm{~K}-1.2 \%$ and $0.6 \%$, and Mg- $0.8 \%$ (only in brown soil). A significant positive correlation between the analyzed macronutrients was confirmed in the soils, with the exception of sulfur and the available forms of phosphorus and potassium in brown soil.
\end{abstract}

Keywords: phosphorus, magnesium, agricultural soil, fertilization, potassium

\section{Introduction}

Factors such as climatic conditions, the crops grown, and the type of fertilization applied are involved in shaping agrochemical properties of arable land [1-4]. Mineral and organic fertilizers applied to soil play a key role, since they are the source of elements in chemical salts or organic compounds, which are subject to specific changes as a result of which mineral nutrients absorbed by plants are released [57]. Among them, macronutrients are of key importance, as they determine crop yield and the quality of crops [8-9]. This is important to intensive agriculture focused on crop production. These types of farms are known to frequently rely solely on mineral fertilizers, which leads to the depreciation of organic matter in soil [10-12].

\footnotetext{
*e-mail: zbigniew.mazur@uwm.edu.pl
}

In the case of farms specializing in the production of livestock, the large amounts of natural fertilizers obtained dictates the necessity to apply them annually. These fertilizers are a substrate for humus [13-17]. In this system of fertilization, the doses of fertilizer have to be adjusted to the conditions of the environment and nutritional requirements of the plants. Taking this into consideration, two long-term field studies were conducted in order to compare the annual application of manure, slurry, and mineral fertilizer on the accumulation of total and available forms of phosphorus, potassium, and magnesium in soils, as well as total sulfur content.

\section{Materials and Methods}

Soil samples from two field studies conducted in the Warminsko-Mazurskie voivodeship (northeastern Poland) 
Table 1. Doses of nutrients applied in the experiments $\left[\mathrm{kg} \cdot \mathrm{ha}^{-1}\right]$.*

\begin{tabular}{|l|c|c|c|c|c|c|c|c|}
\hline \multirow{3}{*}{ Fertilization } & \multicolumn{4}{|c|}{ Experiment I with cow slurry } & \multicolumn{4}{c|}{ Experiment II with pig slurry } \\
\cline { 2 - 10 } & \multicolumn{3}{|c|}{ Average for years 1972-2006 } & \multicolumn{4}{c|}{ Average for years 1973-2007 } \\
\cline { 2 - 10 } & $\mathrm{N}$ & $\mathrm{P}$ & $\mathrm{K}$ & $\mathrm{Mg}$ & $\mathrm{N}$ & $\mathrm{P}$ & $\mathrm{K}$ & $\mathrm{Mg}$ \\
\hline Slurry dI & 111 & 49 & 126 & 20 & 129 & 53 & 80 & 21 \\
\hline Slurry dI + PK & 111 & 67 & 181 & 20 & 129 & 74 & 141 & 21 \\
\hline Slurry dII & 205 & 88 & 227 & 37 & 384 & 182 & 228 & 50 \\
\hline Slurry dII + PK & 205 & 102 & 282 & 37 & 384 & 203 & 289 & 50 \\
\hline Manure & 111 & 37 & 92 & 21 & 129 & 42 & 102 & 19 \\
\hline Manure +PK & 111 & 55 & 147 & 21 & 129 & 63 & 163 & 19 \\
\hline NPK & 111 & 38 & 110 & & 129 & 42 & 122 & \\
\hline
\end{tabular}

*the content of sulfur has not been indicated

in a random arrangement and in six repetitions were analyzed in the experiment. Experiment I was set up in Bałcyny (53³5'45" N, 1951'06" E) in 1972 on lessive soil with the application of natural fertilizers, i.e., cow manure and slurry. Loam characterized by $5-7 \%$ silt and clay fractions is found in the arable layer of the soil. Experiment II

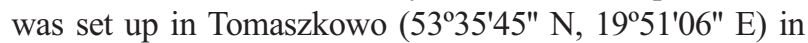
1973 on brown soil with the application of natural fertilizer, i.e., pig manure and slurry. The arable layer contained loamy sand characterized by $2-2.5 \%$ silt and clay fractions.

The study compared the influence of natural fertilizers, i.e., manure and slurry (in two doses), and mineral fertilizers. In addition to farmland fertilized solely by means of natural fertilizers, the experiment also included land supplemented with mineral fertilization (PK). Phosphorus and potassium fertilizers were applied in amounts equivalent to half of the content of these elements used in the event of exclusive mineral fertilization. The design of both experiments was the same and assumed 8 study groups: no fertilization, slurry dose I (dI), slurry dose I + PK (dI + PK), slurry dose II (dII), slurry dose II + PK (dII + PK), manure, manure + PK, and mineral fertilization (NPK). The doses of slurry (dI), manure, and mineral fertilization were balanced with nitrogen. The second dosage of slurry (dII) was determined in such a way that the amount of organic carbon introduced along with it was equivalent to that of the manure dose. The average yearly doses of fertilizer components have been presented in Table 1 .

The following crop rotation was applied in the experiments: potato, spring barely + a mixture of red clover with grasses (in 2 rotations on lessive soil and one on brown soil), winter rapeseed, winter wheat + winter rye aftercrop, corn for silage, spring barely, winter or spring wheat.

The soil samples for the studies were collected after crops had been harvested, from the top layer of the soil ( 0 $25 \mathrm{~cm}$ ), after 34 years of annual fertilization. The contents of available forms of phosphorus and potassium were determined using the Egner-Riehm (DL) method, with magnesium content determined by means of the ASA method following extraction using a $0.0125 \mathrm{~mol} \cdot \mathrm{dm}^{-1}$ solution of
$\mathrm{CaCl}_{2}$. Following the mineralization of soil in a (1:1) mixture of nitric (V) and chloric (VII) acid, total potassium content was established using the flame spectrometry method, total magnesium using the atomic absorption spectrometry (AAS) method, and total phosphorus using the Barton method. The total content of sulfur was determined using the method described by Butters and Chenery.

The results were subjected to statistical calculations using the Statistica 10 software package. The results of each experiment were subjected to statistical analysis using Tukey's analysis of variance. The experiments were compared with the t-test for independent variables, assessing differences between the average results.

\section{Results and Discussion}

The influence of fertilization with slurry on total phosphorus content and the content of its available forms in soil has been presented in Table 2. In the case of lessive soil in the experiment fertilized with cow manure and slurry, the average P-total content was 1.27 times higher than that of brown soil in experiment II, in which the soil had been fertilized with pig manure and slurry. The opposite situation occurred in the case of P-avail., the content of which in brown soil was 1.31 times higher than in lessive soil. The application of solely natural fertilizers in doses balanced with nitrogen and mineral fertilizers (NPK) had a significant influence on the increase of P-total and P-avail. in both types of soil. Manure was found to be the most effective of the above-mentioned fertilizers, whereas dose I of slurry (dI) had the weakest effect with the exception of P-avail. content in brown soil. The second dose of slurry (dII) was more effective in increasing the content of both forms of phosphorus when compared to the first dose (dI) of this fertilizer. Additional fertilization with PK supplementing the use of natural fertilizers had a positive effect on the phosphorus content in the analyzed soils. The average increase of P-total was found to be $0.07 \mathrm{~g} \cdot \mathrm{kg}^{-1}$ in lessive soil and 0.02 in brown soil, whereas the increase of P-avail. was 19.4 
Table 2. Total and available phosphorus content in soils.

\begin{tabular}{|c|c|c|c|c|c|c|}
\hline \multirow{2}{*}{ Fertilization } & \multicolumn{3}{|c|}{ Lessive soil } & \multicolumn{3}{|c|}{ Brown soil } \\
\hline & $\begin{array}{c}\text { Total P } \\
\mathrm{g} \cdot \mathrm{kg}^{-1} \mathrm{~d} . \mathrm{m} .\end{array}$ & $\begin{array}{l}\text { Available P } \\
\mathrm{mg} \cdot \mathrm{kg}^{-1} \text { d.m. }\end{array}$ & $\begin{array}{c}\text { Share P-avail. } \\
\%\end{array}$ & $\begin{array}{c}\text { Total P } \\
\mathrm{g} \cdot \mathrm{kg}^{-1} \text { d.m. }\end{array}$ & $\begin{array}{l}\text { Available P } \\
\mathrm{mg} \cdot \mathrm{kg}^{-1} \text { d.m. }\end{array}$ & $\begin{array}{c}\text { Share P-avail. } \\
\%\end{array}$ \\
\hline No fertilization & 0.79 & 45.9 & 5.8 & 0.61 & 70.2 & 11.5 \\
\hline Slurry dI & 0.87 & 53.2 & 6.1 & 0.73 & 97.7 & 13.4 \\
\hline Slurry dI+PK & 0.95 & 78.9 & 8.3 & 0.73 & 101.2 & 13.9 \\
\hline Slurry dII & 0.95 & 69.8 & 7.3 & 0.75 & 106.4 & 14.2 \\
\hline Slurry dII+PK & 1.02 & 89.4 & 8.8 & 0.79 & 109.4 & 13.8 \\
\hline Manure & 0.98 & 102.9 & 10.5 & 0.78 & 110.3 & 14.1 \\
\hline Manure + PK & 1.05 & 115.9 & 11.0 & 0.79 & 120.3 & 15.2 \\
\hline NPK & 0.92 & 60.6 & 6.6 & 0.75 & 95.0 & 12.7 \\
\hline Average & $0.94^{\mathrm{a}}$ & $77.1^{\mathrm{b}}$ & 8.0 & $0.74^{\mathrm{a}}$ & $101.3^{b}$ & 13.6 \\
\hline $\mathrm{LSD}_{0.05}$ & 0.08 & 8.6 & & 0.07 & 8.8 & \\
\hline
\end{tabular}

$\mathrm{a}, \mathrm{b}-$ insignificant differences at $\mathrm{p}<0.05$

Table 3. Total and available potassium content in soils

\begin{tabular}{|c|c|c|c|c|c|c|}
\hline \multirow[b]{2}{*}{ Fertilization } & \multicolumn{3}{|c|}{ Lessive soil } & \multicolumn{3}{|c|}{ Brown soil } \\
\hline & $\begin{array}{c}\text { Total K } \\
\mathrm{g} \cdot \mathrm{kg}^{-1} \text { d.m. }\end{array}$ & $\begin{array}{l}\text { Available K } \\
\mathrm{mg} \cdot \mathrm{kg}^{-1} \text { d.m. }\end{array}$ & $\begin{array}{c}\text { Share K-avail. } \\
\%\end{array}$ & $\begin{array}{c}\text { Total K } \\
\mathrm{g} \cdot \mathrm{kg}^{-1} \text { d.m. }\end{array}$ & $\begin{array}{l}\text { Available K } \\
\mathrm{mg} \cdot \mathrm{kg}^{-1} \text { d.m. }\end{array}$ & $\begin{array}{c}\text { Share K-avail. } \\
\%\end{array}$ \\
\hline No fertilization & 6.72 & 97.8 & 1.45 & 5.03 & 73.0 & 1.45 \\
\hline Slurry dI & 8.20 & 172.3 & 2.10 & 5.69 & 89.6 & 1.57 \\
\hline Slurry dI+PK & 8.97 & 239.1 & 2.66 & 6.04 & 111.2 & 1.84 \\
\hline Slurry dII & 9.50 & 221.4 & 2.33 & 6.81 & 111.2 & 1.51 \\
\hline Slurry dII+PK & 9.59 & 259.3 & 2.70 & 6.86 & 117.8 & 1.70 \\
\hline Manure & 9.45 & 304.1 & 3.22 & 6.92 & 143.5 & 2.09 \\
\hline Manure + PK & 9.90 & 346.3 & 3.50 & 7.07 & 175.5 & 2.48 \\
\hline NPK & 8.48 & 178.9 & 2.11 & 5.30 & 110.6 & 2.99 \\
\hline Average & $8.85^{\mathrm{a}}$ & $227.4^{\mathrm{b}}$ & 2.56 & $6.22^{\mathrm{a}}$ & $116.8^{\mathrm{b}}$ & 1.95 \\
\hline $\mathrm{LSD}_{0.05}$ & 0.92 & 16.2 & & 0.88 & 11.0 & \\
\hline
\end{tabular}

a - insignificant differences at $\mathrm{p}<0.05$

b - significant differences at $\mathrm{p}<0.05$

$\mathrm{mg} \cdot \mathrm{kg}^{-1}$ and $5.5 \mathrm{mg} \cdot \mathrm{kg}^{-1}$, respectively. The studies of many authors, including Kristaponyte [14], Sienkiewicz at al. [18], Nogalska et al. [19], Li et al. [20], Han et al. [21], Vu et al. [22], Mbah and Onweremadu [23], Ullah et al. [24] and Olson et al. [25], have confirmed the positive influence of applying manure, mineral fertilizers and organic-mineral fertilizers on the total and available phosphorus content. Fertilization also had a positive influence on the participation of P-avail. content in P-total. The average increase in the percentage share of this form of potassium in lessive and brown soil was found to be $2.6 \%$ and $2.4 \%$, respectively, as compared to the control objects. Similar effects were obtained by Maltas et al. [9] when applying manure, slurry, and mineral fertilizers to soil for a period of 12 years.
Table 3 contains numerical data representing the total content of potassium and content of available potassium in soils from the described fertilization experiments. The data show the average $\mathrm{K}$-total and $\mathrm{K}$-avail. content in lessive soil to be 1.42 and 1.95 times higher, respectively, than in brown soil.

The application of manure and slurry (dI) that had been balanced with nitrogen had a significant positive effect on $\mathrm{K}$-total and K-avail. content in both types of soil. This increase was found to be higher in lessive soil than brown soil. Out of all of the fertilizers balanced with nitrogen, manure was found to have the most positive effect on the content of both forms of potassium. The influence of slurry applied in the second dose was lesser than that of manure 
Table 4. Total and available magnesium content in soils.

\begin{tabular}{|l|c|c|c|c|c|c|}
\hline \multirow{2}{*}{ Fertilization } & \multicolumn{3}{|c|}{ Lessive soil } & \multicolumn{3}{c|}{ Brown soil } \\
\cline { 2 - 7 } & $\begin{array}{c}\text { Total Mg } \\
\mathrm{g} \cdot \mathrm{kg}^{-1} \mathrm{~d} . \mathrm{m} .\end{array}$ & $\begin{array}{c}\text { Available Mg } \\
\mathrm{mg} \cdot \mathrm{kg}^{-1} \mathrm{~d} . \mathrm{m} .\end{array}$ & $\begin{array}{c}\text { Share Mg-avail. } \\
\%\end{array}$ & $\begin{array}{c}\text { Total Mg } \\
\mathrm{g} \cdot \mathrm{kg}^{-1} \mathrm{~d} . \mathrm{m} .\end{array}$ & $\begin{array}{c}\text { Available Mg } \\
\mathrm{mg} \cdot \mathrm{kg}^{-1} \mathrm{~d} . \mathrm{m} .\end{array}$ & $\begin{array}{c}\text { Share Mg-avail. } \\
\%\end{array}$ \\
\hline No fertilization & 1.26 & 37.8 & 3.00 & 0.58 & 16.2 & 2.79 \\
\hline Slurry dI & 1.80 & 46.5 & 2.58 & 0.84 & 23.4 & 2.78 \\
\hline Slurry dI+PK & 1.88 & 50.8 & 2.70 & 0.89 & 29.4 & 3.30 \\
\hline Slurry dII & 2.04 & 53.6 & 2.63 & 0.93 & 32.1 & 3.45 \\
\hline Slurry dII+PK & 2.14 & 54.1 & 2.52 & 0.97 & 34.1 & 3.52 \\
\hline Manure & 2.16 & 67.3 & 3.12 & 0.95 & 39.2 & 4.13 \\
\hline Manure + PK & 2.31 & 69.8 & 3.02 & 0.98 & 45.7 & 4.66 \\
\hline NPK & 1.56 & 39.2 & 2.51 & 0.70 & 23.4 & 3.34 \\
\hline Average & $1.89^{\mathrm{a}}$ & $52.4^{\mathrm{b}}$ & 2.76 & $0.86^{\mathrm{a}}$ & $30.3^{\mathrm{b}}$ & 3.50 \\
\hline LSD $_{0.05}$ & 0.16 & 5.2 & & 0.07 & 2.8 & \\
\hline
\end{tabular}

$\mathrm{a}, \mathrm{b}-$ insignificant differences at $\mathrm{p}<0.05$

Table 5. Total sulfur content in lessive and brown soils, $\left[\mathrm{mg} \cdot \mathrm{kg}^{-1}\right.$ d.m.].

\begin{tabular}{|l|c|c|}
\hline \multicolumn{1}{|c|}{ Fertilization } & Lessive soil & Brown soil \\
\hline No fertilization & 148.2 & 79.0 \\
\hline Slurry dI & 168.3 & 99.3 \\
\hline Slurry dI+PK & 178.3 & 107.0 \\
\hline Slurry dII & 180.1 & 124.4 \\
\hline Slurry dII+PK & 211.4 & 134.1 \\
\hline Manure & 210.0 & 99.2 \\
\hline Manure + PK & 225.4 & 107.1 \\
\hline NPK & 159.2 & 84.3 \\
\hline Average & $185.1^{\mathrm{a}}$ & $104.3^{\mathrm{a}}$ \\
\hline LSD $_{0.05}$ & 15.2 & 12.4 \\
\hline
\end{tabular}

${ }^{\text {a }}$ - insignificant differences at $\mathrm{p}<0.05$

with the exception of K-total in lessive soil. Additional fertilization with PK led to an increase in the content of both forms of potassium in the soils. The average increase in the content of K-total was equal to $0.44 \mathrm{~g} \cdot \mathrm{kg}^{-1}$ in the case of lessive soil and $0.19 \mathrm{~g} \cdot \mathrm{kg}^{-1}$ in brown soil, whereas K-avail. was determined at the respective levels of $49.0 \mathrm{mg} \cdot \mathrm{kg}^{-1}$ and $20.1 \mathrm{mg} \cdot \mathrm{kg}^{-1}$ soil. Fertilization caused the percentage share of available potassium in the total potassium content of brown soil to increase by $1.21 \%$ in relation to the control group, whereas the increase in brown soil was $0.58 \%$. Sienkiewicz et al. [18] concluded that the application of manure for several years led to a three-fold increase in the available forms of potassium in soil as compared to the content determined after the application of mineral fertilization. The positive influence of organic fertilizers, including manure and slurry, on the soil content of available forms of potassium has been confirmed by long-term studies of Katkar et al. [26], Shahid et al. [27], and Maltas et al. [9].

The influence of multi-year fertilization on the total and available magnesium content in soil has been illustrated by data compiled in Table 4. The average content of Mg-total in lessive soil was 2.20 times higher, with $\mathrm{Mg}$-avail. 1.73 times higher than in brown soil. Fertilization in doses balanced with nitrogen led to significant increases in the amounts of Mg-total. and Mg-avail., more so in lessive than in brown soil. Manure had the strongest effect, with mineral NPK fertilization having the least. The influence of the application of slurry in the second (higher) dose on the content of both forms of magnesium was lower than in the case of manure, and the difference was higher in experiment I. Additional PK fertilization resulted in an increase in both forms of magnesium. The increase in Mg-total concentration was higher in lessive soil, though Mg-avail. increased more in its brown counterpart. The percentage share of $\mathrm{Mg}$ avail. on fertilized plots of land decreased in lessive soil by approximately $0.27 \%$, but increased in brown soil by $0.81 \%$ when compared to the control plots. According to Sienkiewicz et al. [18], manure has a positive effect on the content of available magnesium. This fertilizer contains magnesium and has a beneficial effect on the sorption complex of the soil, preventing this element from being washed out.

A significant increase in the contents of potassium, calcium and magnesium in the surface layer of the soil after applying manure and slurry for many years was reported in the studies of Emeades [28] and Qian et al. [29].

The total content of sulfur in the analyzed soils has been presented in Table 5. As a consequence of applying natural fertilizers, S-total increased from $20.1-77.2 \mathrm{mg} \cdot \mathrm{kg}^{-1}$ in lessive soil, and from $20.3-55.1 \mathrm{mg} \cdot \mathrm{kg}^{-1}$ in brown soil. The dependence of sulfur content on soil properties in various 
Table 6. Linear correlation coefficients between macronutrient content in lessive and brown soils.

\begin{tabular}{|c|c|c|c|c|c|c|}
\hline \multicolumn{7}{|c|}{ Lessive soil } \\
\hline Macronutrients & Total P & Available P & Total K & Available K & Total Mg & Available $\mathrm{Mg}$ \\
\hline Available P & $0.91 * * *$ & & & & & \\
\hline Total K & $0.96 * * *$ & $0.84 *$ & & & & \\
\hline Available K & $0.94 * * *$ & $0.98 * * *$ & $0.91 * * *$ & & & \\
\hline Total Mg & $0.92 * * *$ & $0.88 * * *$ & $0.95 * * *$ & $0.94 * * *$ & & \\
\hline Available Mg & $0.81 * *$ & $0.94 * * *$ & $0.81 * *$ & $0.95 * * *$ & $0.92 * * *$ & \\
\hline $\mathrm{S}$ & $0.92 * * *$ & $0.96 * * *$ & $0.86^{* * *}$ & $0.95^{* * *}$ & $0.94 * * *$ & $0.93 * * *$ \\
\hline \multicolumn{7}{|c|}{ Brown soil } \\
\hline Macronutrients & Total P & Available P & Total K & Available K & Total Mg & Available $\mathrm{Mg}$ \\
\hline Available P & $0.95 * * *$ & & & & & \\
\hline Total K & $0.79 * *$ & $0.86^{* * *}$ & & & & \\
\hline Available K & $0.77 * *$ & $0.95^{* * *}$ & $0.78^{* *}$ & & & \\
\hline Total Mg & $0.86 * * *$ & $0.80^{* *}$ & $0.94 * * *$ & $0.72 * *$ & & \\
\hline Available Mg & $0.82 * *$ & $0.97 * * *$ & $0.93 * * *$ & $0.95^{* * *}$ & $0.88^{* * *}$ & \\
\hline S & $0.63 *$ & $0.45^{*}$ & $0.77 * *$ & $0.32 *$ & $0.81 * *$ & $0.55^{*}$ \\
\hline
\end{tabular}

significant at $* * * \mathrm{p}<0.001,{ }^{*} \mathrm{p}<0.01,{ }^{*} \mathrm{p}<0.05$

multi-year fertilization systems have been confirmed in the studies of Boye et al. [30, 31]. Additional PK fertilization had a beneficial effect on S-total content, which increased on average by $18.9 \mathrm{mg} \cdot \mathrm{kg}^{-1}$ in lessive soil and $8.4 \mathrm{mg} \cdot \mathrm{kg}^{-1}$ in brown soil. Fertilization with NPK led to an increase in the content of this element in the above-mentioned types of soils by $11.0 \mathrm{mg} \cdot \mathrm{kg}^{-1}$ and $5.3 \mathrm{mg} \cdot \mathrm{kg}^{-1}$, respectively. According to Kopeć and Gondek [32], the content of sulfur in soil when this type of fertilization is applied depends on the dose and form of nitrogen. When applying organic and mineral fertilizers for a few dozen years, Förster at al. [33] determined a higher increase in sulfur content in the case of objects fertilized with manure, and found the increase to be dependent on the dose of this fertilizer.

Table 6 presents the correlation coefficients occurring between the contents of various forms of macronutrients in lessive and brown soils. High correlation coefficients are a result of the phosphorus, potassium, magnesium, and sulfur contents of fertilizers. Lower coefficients between sulfur and the analyzed forms of macronutrients in brown soil may signify that this element is washed out from soil to a greater extent [30, 31].

Of the applied fertilizers, manure was found to have the greatest positive effect on the content of the analyzed macronutrients. The obtained data were thus used to construct conversion factors for both doses of slurry and mineral fertilizers in relation to manure. The average values of the conversion factors were presented in Table 7.

It is recommended that coefficients of fertilization doses be used in precision farming.
Table 7. The average values of the conversion factors.

\begin{tabular}{|l|c|c|c|}
\hline & slurry dI & slurry dII & NPK \\
\hline Lessive soil & 1.16 & 1.03 & 1.18 \\
\hline Brown soil & 1.14 & 1.03 & 1.23 \\
\hline
\end{tabular}

\section{Conclusions}

Long-term annual fertilization with manure, slurry, and mineral NPK fertilizers had a positive effect on the accumulation of total and available forms of phosphorus, potassium, and magnesium in soils, as well as total sulfur content. Among those fertilization doses balanced with nitrogen, manure had the most positive influence on the content of the above-mentioned macronutrients. NPK fertilization was not found to work as effectively as manure, whereas slurry applied in the lower dose had the least influence. The higher dose of slurry balanced with manure using organic carbon also was not as effective. Supplementary mineral PK fertilization applied along with manure and slurry had a significant positive influence on the content of the available forms of phosphorus, potassium, and magnesium in both types of soil, as well as the total sulfur content in lessive soil.

Significant positive correlations were confirmed between the analyzed macronutrients, with the exception of sulfur and the available forms of phosphorus and potassium in brown soil. 


\section{References}

1. KARLEN D.L., DITZLER C.A., ANDREWS S.S. Soil quality: why and how? Geoderma. 114, 145, 2003.

2. JASIEWICZ C., ANTONKIEWICZ J., MAZUR Z., MAZUR T., KRAJEWSKI W. Agrochemical properties of soils fertilized with sewage sludge from sewage treatment plant at Olecko. Ecol. Chem. and Eng. 14, (5-6), 457, 2007.

3. GAMZIKOV G.P., BARSUKOV P. A. VARVAIN O.D. Change in agrochemical properties of sod-podzolic soil during long-term fertilization. Russ. Agric. Sci. 33, 314, 2007.

4. ZHANG X.Y., SUI X.Y., ZHANG X.D., MENG K., HERBERT S.J. Spatial variability of nutrient properties in black soil of northeast China. Pedosphere. 17, 19, 2007.

5. LOPEZ-BUCIO J., CRUZ-RAMIREZ A., HERRERAESTRELLA L. The role of nutrient availability in regulating root architecture. Curr. Opin. Plant Biol. 6, 280, 2003.

6. MANNA M.C., SWARUP A., WANJARI R.H., MISHRA B., SHAHI D.K. Long-term fertilization, manure and liming effects on soil organic matter and crop yields. Soil Till. Res. 94, 397, 2007.

7. SCHOENAU J. J., DAVIS J. G. Optimizing soil and plant responses to land applied manure nutrients in the Great Plains of North America. Can. J. Soil. Sci. 86, 587, 2006.

8. BASRI M.H.A., ABDU A., JUSOP S., AHMED O.H., ABDUL-HAMID H., KUSNO M.A., ZAINAL B., SENIN A.L., JUNEJO N. Effects of mixed organic and inorganic fertilizers application on soil properties and the growth of kenaf (Hibiscus cannabinus 1.) cultivated on bris soils. Am. J. Applied Sci. 10, (12), 1586, 2013.

9. MALTAS A., CHARLES R., JEANGROS B., SINAJ S. Effect of organic fertilizers and reduced-tillage on soil properties, crop nitrogen response and crop yield: Results of a 12-year experiment in Changins, Switzerland. Soil Till. Res. 126, 11, 2013

10. GONG W., YAN X.Y., WANG J.Y., HU T.X., GONG Y.B. Long-term manuring and fertilization effects on soil organic carbon pools under a wheat-maize cropping system in North China Plain. Plant Soil. 314, 67, 2009.

11. SIMON T. The influence of long-term organic and mineral fertilization on soil organic matter. Soil Water Res. 3, 41, 2008.

12. MANDO A., BONZI M., WOPEREIS M.C.S., LOMPO F., STROOSNIJDER L. Long-term effects of mineral and organic fertilization on soil organic matter fractions and sorghum yield under Sudano-Sahelian conditions. Soil Use Manage. 21, 396, 2005

13. LAPA V. V., SERAYA T. M., BOGATYREVA E. N., BIRYUKOVA O. M. The Effect of Long-Term Fertilizer Application on the Group and Fractional Composition of Humus in a Soddy-Podzolic Light Loamy Soil. Eurasian Soil Sci. 44, (1), 100, 2011.

14. KRISTAPONYTE I. Effect of fertilization systems of plant nutrients and soil agrochemical properties. Agr. Res. 3, (1), 45, 2005.

15. LAL R. Challenges and opportunities in soil organic matter research. European J. Soil Sci. 60, 158, 2009.

16. ILUMÄE E., AKK E., HANSSON A., KASTANJE V. Changes the content of organic matter in soil during the whole cycle of crop rotation. Agr. Res. 7, (1), 263, 2009.

17. KOSOBUCKI P., BUSZEWSKI B. Carbon changes in environment, from total organic carbon to soil organic matter. Pol. J. Environ. Stud. 20, (1), 9, 2011.
18. SIENKIEWICZ S., KRZEBIETKE S., WOJNOWSKA T., ŻARCZYÑSKI P., OMILIAN M. Effect of long-term differentiated fertilization with farmyard manure and mineral fertilizers on the content of available forms of $\mathrm{P}, \mathrm{K}$ and $\mathrm{Mg}$ in soil. J. Elementol. 4, 79, 2009.

19. NOGALSKA A., CZAPLA J., SKWIERAWSKA M. The effect of multi-component fertilizers on spring triticale yield, the content and uptake of macronutrients. J. Elementol. 4, 95, 2012.

20. LI X., DONG C., LIU Y., LIU Y., SHEN Q., XU Y. Interactive effects from combining inorganic and organic fertilisers on phosphorus availability. Soil Res. 50, (7), 607, 2012.

21. HAN XZ, SONG CY, WANG SY, TANG C. Impact of longterm fertilization on phosphorus status in Black Soil. Pedosphere. 15, 319, 2005.

22. VU D.T, TANG C, ARMSTRONG R.D. Changes and availability of $\mathrm{P}$ fractions following 65 years of $\mathrm{P}$ application to a calcareous soil in a Mediterranean climate. Plant and Soil, 304, 21, 2008.

23. MBAH C.N., ONWEREMADU E.U. Effect of Organic and Mineral Fertilizer Inputs on Soil and Maize Grain Yield in an Acid Ultisol in Abakaliki-South Eastern Nigeria. AmEuras. J. Agr. 2, (1), 7, 2009.

24. ULLAH M.S. ISLAM M.S., ISLAM M.A., HAQUE T. Effects of organic manures and chemical fertilizers on the yield of brinjal and soil properties. J. Bangladesh Agril. Univ. 6, (2), 271, 2008.

25. OLSON B.M., BREMER E., MCKENZIE R.H., BENNETT D.R. Phosphorus accumulation and leaching in two irrigated soils with incremental rates of cattle manure. Can. J. Soil Sci. 90, 355, 2010.

26. KATKAR R.N., SONUNE B.A., KADU P.R. Long-term effect of fertilization on soil chemical and biological characteristics and productivity under sorghum (Sorghum bicolor) - wheat (Triticum aestivum) system in Vertisol. Indian J. Agric. Sci. 81, (8), 734, 2011.

27. SHAHID M., NAYAK A.K., SHUKLAA.K., TRIPATHI R., KUMAR A., MOHANTY S. Long-term effects of fertilizer and manure applications on soil quality and yields in a subhumid tropical rice-rice. Soil Use Manage. 29, 322, 2013.

28. EDMEADES D.C. The long-term effects of manures and fertilizers on soil productivity and quality: a review. Nutr. Cycl. Agroecosyst. 66, 165, 2003.

29. QIAN P., SCHOENAU J.J., KING T., JAPP M. Effect of repeated manure application on potassium, calcium and magnesium in soil and cereal crops in Saskatchewan. Can. J. Soil Sci. 85, 397, 2005.

30. BOYE K., ERIKSEN J., NILSSON S.I., ERIKSEN J. Net sulfur mineralization potential in Swedish arable soils in relation to long-term treatment history and soil properties. Biol. Fertil. Soils. 45, 743, 2009.

31. BOYE K., ERIKSEN J., NILSSON S.I. MATTSSON L. Sulfur flow in a soil-plant system - effects of long-term treatment history and soil properties. Plant Soil. 334, 323, 2010.

32. KOPEĆ M., GONDEK K. The effect of long-term fertilization on the sulphur content in soil and in the mountain meadow sward (Czarny Potok). Rostlinná Výroba. 48, (12), 525, 2002.

33. FÖRSTER S., WELP G., SCHERER H.W. Sulfur specification in bulk soil as influenced by long-term application of mineral and organic fertilizers. Plant Soil Environ. 58, 316, 2012. 